\title{
Theoretical and Practical Research Orientations in German Economics
}

\author{
Arnold Wilts
}

The field of economics typically is considered a very successful discipline, distinguishing itself not only by the scientifically advanced and mathematically articulated character of its theories and research methods, but also by the profoundlyapplied nature of theknowledge and insights it produces (Medema and Samuels, 1996). Despite their often abstract and mathematical character, the knowledge and insights of economics generally are considered to be of major importance for effective economic organisation and political administration. Research in economics thereforeis done within the cognitive band width between highly specialised theoretical research themes on the one hand and practically oriented, applied research questions on the other hand. The process of cognitive change and intellectual innovation in thefield of economics thus has a 'hybrid' character in that it results both from an inner-scientifically gener- ated cognitivedynamic and from theimperatives emerging from external demands for applicable knowledge and insights (Whitley, 1984: 226).

This paper discusses questions of the relation between internal dynamics and external imperatives in the knowledge process within the field of economics. Such questions are central to the philosophyand methodology of economics, where the scientific nature and practical relevance of the field's theories and insights are assessed (cf. Backhouse, 1994). An issue which often is not addressed in methodological reflections, however, is what the actual incentives areunder which economists orient their research towards theoretical or practical priorities. How does the way in which research is organised, structure the way in which economists actually take up theoretically advanced and methodologically articulated research topics? Alternatively, under what conditions do 
economists orient their research towards the practical priorities emerging from economic and political decisionmaking in stead? This paper provides empirical answers to these questions based on a series of extensive interviews held with German economists.

In the next paragraph recent theoretical accounts of research practice and organisation are discussed so as to position the topic of this paper to current developments in the sociology of science and technology. After that, the main features of organised and publicly-funded economic research in Germany are sketched and general differences between the research orientations of German economists are discussed. In the fourth and fifth paragraph of the paper the results of the interviews that were held with two groups of economists are presented. These two paragraphs focus on economic research at publiclyfunded, non-academic institutes and at German universities respectively. On the basis of the theoretical discussion and empirical results, the paper in conclusion specifies questions for further research into the institutional linkages between scientific research and its practical economic and political contexts.

\section{Forms of Research Organisation}

Recent work in the sociology of science and technology (STS) has shown that characteristics of the organisation of research practices are intricately linked with cognitive features of knowledge production (Pickering, 1992). Thereby, traditional analyses of reward structures and reputational hierarchies in science have been extended to include the material conditions of research and the po- litical character of the maintenance of its cognitive boundaries (Latour, 1987; Gieryn, 1995).

Constructivist studies, in particular, have argued that research practices are essentiallystructured by contingent and culturally specific circumstances. These studies have thereby demonstrated that the research process in many ways is conditioned by the practice relations of researchers, for instance those towards the government bureaucracy (Cozzens and Woodhouse, 1995). Thisobservation particularly pertains to the development of the social science disciplines which has been closely related to broader processes of societal change (Wittrock et al., 1991). Being one of the main social sciencedisciplines, especially the history of economics cannot be separated from changes in the economic and political organisation of modern society (Galbraith, 1991).

The theories and insights of economics have often emerged directly from practical economic considerations and political demands for specific forms of knowledge and expertise (cf. Polanyi, 1957, chapters 6 and 10; Wagner, 1990, chapters 5 and 8 ). Economic knowledge especially was of importance to the build-up of the policy arrangements that have becometypical for theadministrative organisation of modern welfare states (Weir and Skocpol, 1985; Hall, 1989). Economists today are heavily involved in the management of those welfare states and the field derives much of its social status and professional recognition from those practical activities (see Coats, 1993). This observation makes the question of the institutional organisation and the intellectual orientation of economic research all the moreinterest- 
ing, given the potential relevanceof economic knowledgefor understanding the political pressures emerging from current economic changes (OECD, 1997; Monti, 1997).

Questions concerning the organisation of scientific work and external influences on the knowledge process, moreover, have recently received widespread attention as it has been argued that a new and essentially transdisciplinary form of knowledge production is now emerging (Gibbons et al., 1994; reviewed by Godin, 1998). Arguably, this new mode of research organisation generates knowledge which is inherently reflexive and socially accountable in terms of its theoretical contents and empirical applicability. On a similar note, it has been argued that modern research practice is now developing into the direction of 'post-normal' science, primarily characterised by a reflexive and value-sensitive methodology (Funtowicz and Ravetz, 1993). Also, it has been demonstrated that research practices are more and more becoming embedded in new networks of intricate relations between scientific, economic and political domains, causing knowledge production to beever moreattuned to practical demands and expectations (Leydesdorff and Etzkowitz, 1996; Etzkowitz and Leydesdorff, 1997; Jacob, 1997).

It is as yet an open question, however, whether the emergence of new forms of research organisation are a general phenomenon, marking a fundamental changein modern science(Shinn, 1999). Related to this, the question still remains to beanswered of whether new forms of research organisation emerge in addition to existing forms of work organisa- tion in science or, alternatively, whether they will be replacing established forms of knowledge production. Any reliable characterisation of possible changes in the organisation of knowledge practices in terms of their generality and uniqueness thus depends on empirical information about the responsiveness of existing forms of research towards the external imperatives that emerge from actual economic developments and political decision making (Weingart, 1997). More in particular, such a characterisation must be based on knowledgeabout the extent to which the organisation of research entails mechanisms that link research to the practical demands and expectations of actors in the economic and political sector (Mayntz and Schimank, 1998).

Analysing the organisation of knowledge production in economics thus depends on empirical insight into the way in which economists actually do their scientific work and into the conditions under which they choose to orient their research towards disciplinary and theoretical priorities or towards practical and applied priorities in stead. The next paragraphsseek to providesuch insights by presenting the results of a series of expert interviews held with German economists working in different research contexts.

\section{The Organisation of Economic Research in Germany}

The question of what the incentives are under which economists orient their work towards external priorities of practical decision-making outsideacademia or, alternatively, towardsinner-scientifically generated priorities of theoretical 
consistency and methodological adequacy can only be answered empirically. This question was the topic of forty-one interviews held with two groups of German economists (seeWilts, 1999). Theseinterviews weresemi-structured and addressed threemain themes. Firstly, the procedures in which economists identify relevant research problems. Secondly, theroleand influence of external actors in the identification of such problems. Thirdly, the cognitive preferences and professional interests that underlie economists' choice for theoretical and practical research orientations. The interviews were thus meant to gain insight into the way in which the institutional structures in which German economic research is embedded allow economists to perceive and take up practically relevant or scientifically meaningful research problems.

\section{The Context of the German Research System}

The institutional structures in which economic research is embedded, vary considerably across sectors of the German research system (cf. Hohn and Schimank, 1990). A general characteristic of that system is its large sector of publicly-funded non-university research (Mayntz 1991; Schimank, 1996). Within thenon-university sector there areseven institutes for applied economic research. These are the Institute for Economic Research in Munich (IFO), The German Institute for Economic Research in Berlin (DIW), the Hamburg Institute for Economic Research (HWWA), the Kiel Institute of World Economics (IfW), the Rhine-Westphalia Institute for Economic Research in Essen
(RWI), the Institute for Economic Research in Halle(IWH), and the Centrefor European Economic Research in Mannheim (ZEW).

These institutes are partly financed out of public means and pursue applied, empirical research which often is of great relevance to economic policy decision-making. An important task of these institutes, for instance, is collecting empirical information about economic developments and making this information available to decision-makers in the private and public sector. The institutes for example annually publish economic prognoses that are highly visible in the media and often lead to political debate.

Economic research in thenon-university sector thus is distinctly practical in character and primarily done with empirical research techniques (Gerlach, 1993). The applied character of their research is an important reason for the public funding of theseven non-university institutes. Their work is thought to supplement university research, which often is primarily concerned with fundamental theoretical topics and research questions. Because of theapplied character of their research, however, these institutes are only partially financed out of public means (Table 1 ). Thereby, economic research outside academia is forced to find additional funding from the privateand public sector.

In addition to the non-university sector, economic research is done at most of the eighty-three universities in Germany (Kirman and Dahl, 1996: 73-85). Academic economics distinguishes itself from theeconomic institutes in thenonuniversity sector of the German research 
Table1. Budgets in million Dm and staff of the non-university institutes in 1995 (Wissenschaftsrat 1998: 35)

\begin{tabular}{lcccrr} 
Institute & $\begin{array}{c}\text { Total } \\
\text { budget }\end{array}$ & $\begin{array}{c}\text { Institutional } \\
\text { funding }\end{array}$ & $\begin{array}{c}\text { Additional } \\
\text { funding }\end{array}$ & $\begin{array}{r}\text { Number } \\
\text { of staff }\end{array}$ & $\begin{array}{r}\text { Research } \\
\text { staff }\end{array}$ \\
\hline IFO Munich & 34.2 & 15.4 & 18.8 & 245 & 141 \\
DIW Berlin & 30.8 & 16.8 & 14.0 & 209 & 97 \\
HWWA Hamburg & 22.7 & 21.4 & 1.3 & 220 & 72 \\
ZEW Mannheim & 19.5 & 13.9 & 5.6 & n.d. & n.d. \\
IFW Kiel & 15.6 & 12.4 & 3.2 & 164 & 66 \\
RWI Essen & 9.9 & 7.5 & 2.4 & 75 & 46 \\
IWH Halle & n.d. & n.d. & n.d. & 66 & 37
\end{tabular}

system in two important respects. Firstly, higher education in economics exclusively lies within thecompetence of universities and forms an integral part of their institutional mission (Schimank, 1995). This provides university research with a strong institutional basis. Secondly, research within the academic organisation of the field rangesfrom business and general economics to mathematical economics and econometrics and thereby is more broadly oriented thematically than the work of the nonuniversity institutes.

Particularly research in fields of general or macroeconomics, however, shares possible relevance to practical economic policy decision-making with the work of the seven non-universityinstitutes for applied economic research. General or macroeconomic research at German universities, however, often is of an marked theoretical nature and generally pursued with advanced mathematical methods (Wissenschaftsrat, 1998: 15-16). Regarding the question of how research topics are generated, university research on general economic terrain therefore is particularly interesting when compared with the work of the non-university institutes.

In contrast to the organisation of the large non-university institutes, university organisations such as chairs, institutes and research departmentsare relatively small. Teaching and research generally are organised in organisational units employing only a few assistants and research staff. Within the German university system, individual professors have close to full autonomy concerning the contents of their teaching and research (see Karpen, 1991). University research in economics, moreover, mainly isfinanced from regular university budgets, supplemented with research grants from national and international funding bodies. Academic research thus is pursued in the context of relative financial security and well-entrenched cultural norms of academic autonomy and scientific independence(Schimank, 1995).

With reference to the question of how theoretical and practical priorities are rendered into actual research orientations of economists it is further 
important to note that the German constitution explicitly states that every form of research, be it in the university or in the non-university sector, is and should be free and independent from external interference. The constitutionally warranted freedom of research, however, does not include financial independence(Knemeyer, 1996). Research in both the university and the non-university sector, al beit to a varying extent, rely on institutional and additional external funding. It follows that economic and political actors might try and direct research into the direction of practical priorities through the financial appreciation of certain forms of knowledge or expertise (Schimank, 1994). It also follows that the extent to which economic and political actors can do so is structured by the actual proportion between institutional and additional funding across sectors of the German research system (Mayntz, 1991).

In the university sector basic funding is allocated through regular university budgets. Additional research funding may befound through funding agencies at the national, increasingly also at the European level (cf. Kirman and Dahl, 1996: 76-77). Applying for funds distributed through such agencies, however, generally follows only voluntarily and at theinitiativeof individual researchers at that. University researchers, by consequence, areableto seek third party funding primarily on the basis of their own preferences and interests. This limits the extent to which external demands can be mediated into research priorities within academia through the distribution of additional research funding (cf. Rip, 1994).

Grantapplication, moreover, doesnot necessarily mean that research need be oriented towards considerations of practical applicability. Funding agencies in many ways areableto represent the fundamental research interests of thescientific community and do not necessarily build in external demands into grant assessment procedures (Braun, 1998). In grant application procedures at the main funding agency in Germany, the German research Society (Deutsche Forschungsgemeinschaft), theoretical considerations in stead of criteria of practical applicability do for instance play a major role in assessing proposals for the funding of economic research (Hartmann, 1990: 114-117).

The financial arrangements in which research in the non-university sector is embedded, in contrast, are very much different. The seven institutes for applied economic research outside academia largely depend on contract research as a source of additional research funding. The access to additional funding therefore depends on established contacts between these institutes and their major clients in the private economy and particularly the government bureaucracy. Such contacts arefacilitated by the contents of existing contract portfolios, established research traditions and accumulated expertise. On average, the institutes realise about a third of their annual budgets through additional funding in the form of research grants and, in particular, contract research for clients in the private and public sector (Wissenschaftsrat, 1998: 35). Thismeans that theinstitutes/argely depend on third party funds and are therefore forced to adjust their research goals, their strategic decision-making procedures and their internal allocation 
of available resources to changing external demandsfor applied knowledgeand practical insights.

\section{Economic Research in the Non-university Sector}

The observations of the previous paragraphs form the background for the presentation, here and in the next paragraph, of the results of a series of extensive interviews held with German economists. The first group of economists that were interviewed consisted of twenty-four senior researchers at one of the seven publicly-funded non-university institutes for applied economic research in Germany. Theresearchers that wereinterviewed at these institutes were heads of research divisions on such terrainsaseconomic trends, industrial economics or international financial markets. They were asked to reflect on three themes. Firstly, the nature and organisation of their institute's internal decision-making procedures regarding the orientation and build-up of research programmes. Secondly, the role of external actors in those decision-making procedures. Thirdly, the thematic orientation and actual contents of their institute's research efforts.

\section{Internal Decision-making and External Relations}

Regarding the institutes' decision-making procedures it was emphasised in all interviews that decision-making within extra-academic institutes has to beflexible enough to be able to respond to quickly changing external demands for applied knowledge and practical expertise. Yet, such decision-making has to be robust enough to uphold a recognisable research profile. Thesize of theinstitutes combined with the fact that they greatly rely on external sources of research funding thus forces them to formally organisetheir strategic research planning. In all institutes, therefore, annual research plans are drawn up. These plans identify fundamental research goals and specify thematic priorities to which the work of individual researchersismoreor less directly constrained through internal decision-making procedures and formal task assignments.

External contacts, that is, contacts with representatives of clients and addressees in the private and public sector, areimportant information channels for the institutes when orienting their research towards practically relevant research topics. This hold in particular for contacts in the context of contract research projects, which form the main channel through which external actors can influence actual decision-making within the various economic institutes. Such negotiations, however, often represent only an "indirect influence" on research, according to the interviewees, meaning that clients do influence the general direction of research butthat decisions as to the validity and reliability of concrete research results exclusively liewithin the competence of the various

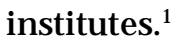

It was repeatedly observed by the interviewees, however, that regular contacts with economic and political actors do often lead to questions and problems that had not been observed before. Such projects generally "emerge from building up a network, largely consisting of personal acquaintance and of privateassessment". Within the various institutes 
individual staff therefore often is given considerable freedom in maintaining personal contacts with actors in theeconomic and political sector. The practical influence of such actors on actual research was positively valued since it was said to enable the institutes to adjust their work effectively to external demands and considerations. Given thefinancial dependence of the institutes upon external funding through contract research, adjusting their research to external demandsis of crucial importance to them. The introduction of the practical questions and expectations of clients and financiers into the research orientations of the various institutes, then, largely is an intended yet in its concrete form unanticipated result of maintaining networks of informal contacts with economic and political actors.

Additionally, doing contract research also brings along more formally organised ways in which external actors can try and influence the general direction and actual contents of concreteresearch projects. This holds in particular if such projects are relatively large in terms of necessary timeand personnel resources. Such projects are subject to relatively direct external influences:

In such cases, of course, clients want to be informed regularly about the progress of the project and might want to discuss preliminary results during its duration. Meetings are organised then at which one presents and discusses such results and where clients can suggest further research steps or criticise others. In that way clients do influence the actual research process, thereis no question about that.

\section{Research Funding and Research Orientations}

Different forms of research funding were repeatedly mentioned in the interviews as being correlated to variation in the contents and intellectual orientation of individual research projects. Research for political institutions such as theFederal Ministry of Economic Affairs in Bonn or theEuropean Commission generally is output oriented. Research funded trough national funding agencies such as the German Research Society (DeutscheForschungsgemeinschaft), in contrast, is more likely to address basic conceptual and methodological issues.

It was emphasised that the freedom of individual members of the institutes to maintain external contacts also includes thefreedom to apply for research funding at theappropriateorganisations and funding bodies. In doingso, the applied research in thenon-university sector is however confronted with a problem because of the "very high standards" which grant applications at academic funding agencies generally need to meet. A number of interviewees mentioned in this respect that, under the pressure of the budget and time constraints non-university research is confronted with, therelatively high rejection rate of grant proposals does not justify the necessary investment of resourcesin the daily practice of research.

Instead of applying formally for third party funds, theinstitutes sometimes cooperate directly in taking up larger research projects with organisations in the private or public sector - such as inhouse research divisions of ministries or large financial institutions. Generally, the economic research institutes make their accumulated research expertise availableto their co-operation partners. 
These, on their turn, provide practical information and empirical data, which are of importance to the institutes' ability to anticipate future demands for particular forms of applied knowledge and practical expertise. Such joint activities, however, are limited to those occasions where "there are clear advantages for us and our partners", as on interviewee put it.

\section{Network Relations between the Institutes}

The seven institutes for applied economic research in the non-university sector do form a network among themselves which influences their strategic decision-making as to the direction of research and the intellectual orientations of its outcomes. This was described as determining where there is the "possibility of occupying a niche" in the market for applied economic research. Thereby, the research profiles of the individual institutes may be strengthened, on its turn enhancing chances to acquire future contract projects and additional research funding. As a consequence, economic research outside academia is decidedly empirical in character and strongly oriented towards priorities emerging from practical economic and, in particular, political decision-making.

It was observed in one interview, for instance, that non-university economic research "is meant to support a particular economic policy" by embedding specific policy questions in a more general theoretical framework. For this reason, the institutes need to actively anticipate what kind of practical questions will come up under the pressure of actual economic and political developments. The main channel through which this is achieved, next to contract research, is maintaining informal contacts with representatives of external addressees:
Many of these contacts are of a very personal nature. One has known the peoplefor four or fiveyears, and meets them often. This is not necessarily re- lated to scientific problems, but through such contacts onelearns what actually concerns people. At some point that information enters into our research, although its actual influence might not be visible in terms of con- crete research output.

In this context, it was also observed that the necessity of attuning their research to practical considerations does pose a problem for the non-university institutes in that their research staff "becomes output-oriented as well and eventually only discusses empirical results" in stead of more fundamental theoretical issues and methodological questions. Within the context of frequent interaction with external actors, economists then develop cognitive preferences and practical research interests that enable communication with economic and political decision-makers. This discourages them to work on theoreticallyadvanced and methodologically articulated research topics and limits the opportunities for these economists to obtain individualised scientific reputation through publications in the international literature.

\section{Practical Research Priorities}

Regarding the themes on which interviewees at the seven non-university institutes wereasked to reflect, then, three conclusions can be drawn. Firstly, the 
internal decision-making procedures underlying theinstitutes' research planning allow them to adjust their research to changing external demands for applicableknowledge while enabling them to orient the research efforts of their individual members towardsorganisational goals and priorities. Secondly, external actors do play a rolein internal decisionmaking processes within the various institutes, either directly in the context of contract research projects or indirectly through informal contacts and personal communication. Thirdly, the thematic orientation and actual contents of research in the non-university sector are strongly geared to external demands for applicable knowledge and empirical insights into policy-relevant issues. This form of research thus leads to output which enables communication across the boundaries of the economics discipline but which at the same time constrains communication within thescholarly community within the field.

\section{Economic Research at German Universities}

Next to the seven non-university institutes, seventeen interviews were held at five leading German universities, namely those at Bonn, Cologne, Freiburg, Kiel and Munich. At these universities professors in macroeconomic fields such as general economic theory, economic policy, and public finance were asked to reflect on three themes. Firstly, the decision-making procedures in which scientifically meaningful or, alternatively, practically relevant research topics are identified. Secondly, the nature of the contacts maintained within and across the boundaries of the scien- tific community in the field of economics. Thirdly, the relative weight of theoretical or practical considerations in the identification of research problems and, closely associated with this, theapplicability and the degree of mathematical formalisation of research results.

\section{Inner-scientific Orientations}

Themain conclusion emerging from the interviews with academic economistsis that topics of general economic research at German universities are predominantly identified on the basis of innerscientific criteria of theoretical consistencyand methodological adequacy. Furthermore, economics professors can largely determineindividually what relevant research problemsare. In thecontext of the German university system, their tenure supplies them with considerable intellectual freedom and academic autonomy, includingtheability to largely determine the theoretical and methodological orientation of the research of their assistants and associates. It was mentioned in the interviews without exception that problems of general theory and methods are primarily mediated into individual research through the international literature in the field:

It is strongly directed through the literature. Oneobserves what themes are currently en vogue in thejournals, what themes can attract attention, what models have been developed on the basis of which one might identify a body of literature about which onecan write.

Regarding the differences between academic research and the work of the seven non-university institutes, it was repeatedly pointed out in theinterviews 
that basic intellectual innovations cannot materialise in the context of the applied research outside academia. The institutes in the non-university sector would not havethecapacity to invest the time and effort necessary for doing ground breaking research. Once established, however, new methods and research topics can be taken over by the non-university institutes with great effect, according to one interviewee, precisely because of their relatively large resourcesand established research routines.

In this respect it was observed that research in economics almost always has some sort of practical meaning even if strictly oriented towards theoretical goals and priorities. This would hold for insights resulting from inner-scientifically generated theoretical developments as well as for insights emerging directly from reflections on current economic developments and political debates. Particularly such debates were mentioned as a potentially "motivating factor" since, from many interviewees' points of view, these debates often do "not take place on a very high intellectual level". Contributing to the refinement of public debate was therefore mentioned repeatedly as an important task of academic economic science. This generally does not mean, however, that workin academic economics is oriented towards research priorities emerging directly from practical and extra-scientific considerations.

The interviewees at the various universities emphasised without exception the professional importance of maintaining contacts within the scholarly community. It was observed in this respect that most feedback on the actual contents of scientific work comes from fellow economists in the international community within the field. Such feedback to an important extent is mediated through scientific meetings and conferences as well as through the informal exchange of working papers and research proposals. In addition, electronic communication was repeatedly mentioned as being increasingly important for the exchange of information and professional opinion.

\section{Research Funding and Research Orientations}

With regard to the funding of research it was suggested that the organisation of university research does not provide manyincentives for acquiringadditional funding through formal grant application procedures. Since acquiring such funds has virtually “no effect upon one's other obligations" such as teaching and university administration, theincentive "to actively seek external research funding is extraordinarily weak". Apart from actual research projects, however, additional funding might be applied for to finance organising seminars and workshops. Often representatives of organisations in the public and private sector - such as researchers at in-house research divisions of government ministries, central banks and large financial institutions - are invited to such meetings. In the interviews those seminars and workshops were mentioned repeatedly as important channels for maintaining contacts to economic and political practice.

Contacts to external actors in the context of scientific meetings may lead the latter to initiate contract research 
projects. In this respect it was mentioned that the in-house research in government bodies and financial organisations is becoming ever more "scientific" partly because of the increasing availability of computing facilities and accessible data sets - and this, arguably, "makes the communication with their representatives not only more interesting, but also a lot easier". Furthermore, it was stressed that there are clear differences between essentially scientific and more directly practical research interests, but that there generally is enough common ground for a "close connection" with such external representatives.

In comparison to non-university research, however, academic economic research is highly formalised and often does not generate results that are easily applicableto practical problem-solving. It was stressed in this respect that the relevance of academic research does not lie in its practical applicability so much, but in its theoretical potential in stead. One interviewee for instance said about theoretically oriented and mathematically articulated work in academia:

In that way one can discriminate among different theories. That normally is not possiblein applied, empirical research because there are always multiple hypotheses that are compatible with the observed reality. Often it is very difficult then to discriminate, when one cannot really control every aspect of the problem.

Generally, it was stressed that work on abstract economic models often does not require nationally specific data, that is, concrete institutional information abouteconomic and political structures. Academic research often "is independent from institutional characteristics of the data", but in stead more likely to be focussed on "problems of general economic theory".

Different Positions in the Reputational Hierarchy

In the interviews at the various universities it was stressed that only topics are taken up that are likely to generate articles in the international journals, because only thesekind of articles can lead to the scientific reputation that one needs for an academic career in economics. Against this background, there is not a particularly strong incentive for younger economists - who still need to establish a position in the reputational hierarchy in the field - to do empirical research, that is, research which specifically concerns issues of national economic policy decision-making. Rather, these economists are particularly encouraged to work on those topics of economic theory which are publishable in the international literature, thereby employing advanced mathematical methods and research techniques and often abstracting considerably from national economic and political contexts. Exceptions arethoseeconomists who strivefor a career outside academia and who are morelikely to do work - for instancedissertation research - which is geared to practical considerations of economic organisation and political decisionmaking.

Older and more established economists, who have al ready acquired a position in the reputational hierarchy within the field, may orient their scientific work more explicitly towards practical questions and research topics. One interviewee went so far as to state that 
he writes "almost exclusively for audiences outsi de the community of professional economists". The reason for this would lie in the fact that macroeconomic research should investigate topics with a direct relevance to economic policy decision-making. Therefore, the "efficiency rate" of research would be higher when actual decision-makers are reached in stead of "only a few theoreticians" which would be reached through theoretically advanced and methodologically articulated publications in the international literature within the field.

It was also observed during the interviews that at time contracts for doing applied research for economic and political clients areaccepted that continue more basic research, performed earlier. The theoretical insights produced in such earlier research arethen used as the thematic basisfor investigating concrete and applied research questions. It also happens, however, that applied questions cannot be readily answered on the basis of earlier established insights. In that case, contract projects can further fundamental and moretheoreticallyoriented research work. It was remarked, however, that theacceptance of contract projects primarily depends on whether or not required research orientations fit the personal ideas and cognitive preferences of the individual researchers that need to work on such projects. In that respect, the "theoretical position" and personal preferences of the individual researchers involved "Iargely determine what kind of applied questions" will be worked upon, the freedom to do so being warranted by the academic autonomy of full professors in the context of the German university system.

In the German social and cultural context academic or scientific independence thus is a constitutive feature of theeconomics discipline's self-image. This translates into theoretical and inner-scientifically oriented research orientations within academia. Economists striving for an academic career are therefore likely to develop cognitive preferences and research interests that can yield individualised scientific reputation, that is, thetypical form of professional recognition necessary for gaining access to theinstitutional resources that are available within the academic organisation of the field. The organisation of academic research in economics in Germany thus confronts individual economists in their local work environments as typical and relatively strong incentives to produce work oriented towardsinner-scientific priorities of theoretical consistency and methodological adequacy. This kind of work, then, precipitates in research output understandable only to well-trained specialists, shielding research off from direct external demands and largely reproducing thecharacter of the field as being primarily a theoretically oriented disciplinary science.

\section{Theoretical Research Priorities}

Regarding the three themes on which interviewees at the various universities wereasked to reflect, then, threeconclusionscan bedrawn. Firstly, the decisionmaking procedures underlying research planning in the university sector are informal up to the point that they become identical to thepersonal preferencesand interests of individual economists. The financial and institutional structures of academically organised research, how- 
ever, provide relatively strongincentives for economists, particularly for younger economists, to work on scientifically meaningful research problems, that is, those topics that are being recognised in the international literature within the field as theoretically or methodologically relevant. Secondly, contacts within the scholarly community of economists are of great importance for acquiring and maintaining the scientific reputation necessary for establishing oneself in the disciplinary hierarchy of the field. Against this background, it is the older and already established economists, in particular, who are most likely to maintain networks of external contacts with actors in theeconomic and political sector. Thirdly, considerations of theoretical consistency and methodological adequacy play a major role in identifying research topics. This precipitates in often highly formalised and mathematically articulated forms of research and shields the knowledge process in the field off from direct external goal setting on the basis of practical considerations.

\section{Conclusion}

University and non-university research in the field of German economicsispursued in two structurally different institutional settings. These provide economists with different incentives and opportunities with regard to the choice for research topics, research methods and publication outlets. The main intellectual orientations underlying economic research in Germany, consequently, differ across the two main sectors of the country's research system. University based economists, working in fields of general of macroeconomics, are more likely to pursue theoretical, often highly abstract research goals and generally prefer methodologically articulated research techniques. Economists working at publicly funded research institutes outside academia, on the other hand, often focus on applied research goals in stead and generally prefer empirically grounded research methods and statistical techniques.

The interviews with German economists, then, show that the knowledge process in economics can respond more or less directly to the practical priorities that emerge from actual decision-making in the private economy and government bureaucracy. It can only do so, however, to the extent to which the institutional characteristics of research practices in the field allow economists to link practical problems to the cognitive issues that are being perceived as relevant in their particular work environments (cf. Breslau, 1993). The institutional characteristics of research practices, that is, the organisational principles and financial arrangements that make up such environments, confront individual economists as different incentive and opportunity structures. These encourage them to take up particular research themes and discourage them to take up others.

The organised production of economic knowledgecan thereforerespond to external priorities emerging from practical economic and political decision-making to theextent to which those priorities can beintegrated into research work that can yield desired forms of professional recognition. Within thevarious sectors in the German research system these forms of recognition differ fundamentally, ranging from scientific repu- 
tation in the academic hierarchy of the field to the external acknowledgement of practical knowledge and skills in the context of the publicly-funded research institutes outsi de academia.

These observations, then, lead to questions for further and comparative research into the relations between the institutional organisation of research on the one hand and the intellectual orientations and cognitive preferences of individual researchers on the other. How do organisational principles and financial arrangements provide concrete incentives and constraints for researchers to perceive and take up either theoretically recognised or practically appreciated research topics? How do the results of research on such topics on their turn influence what questions can subsequently be perceived as being scientifically meaningful or practically relevant?

Answering these questions on the basis of empirical research will provideinsightinto the responsiveness of scientific research towards external demands for applied knowledge and practical expertise. Thereby, the circumstances in which researchers are morelikely to orient their work towards inner-scientifically generated priorities or, alternatively, towards external priorities emerging from practical decision-making in the private and public sector can be compared and classified. This would contribute to understanding the conditions under which new forms of work organisation can emergein the everyday practice of research. More in particular, it would enable a comparative analysis of the effects of the emergence of new forms of research organisation on the cognitive orientation of the research process.
Acknowledgements

I want to thank Raymund Werle, Markus Winnes and the Editors of this journal for helpful comments. Also thanks are due to Renate Mayntz and the economists who have offered their time being interviewed.

\section{Notes}

1 The quotes in the text are translations taken from theoriginal German interview transcripts. See Wilts (1999) for an extended presentation of the interviews with economists working in the non-university and university sector of the German research system.

\section{References}

Backhouse, R.E.

1994 "Introduction, New directions in economic methodology." Pp. 1-26 in Backhouse (ed.), New Directions in Economic Methodology. London and New York: Routledge.

Braun, D.

1998 "The Role of Funding Agencies in the Cognitive Development of Science." Research Policy 27: 807-821.

Breslau, D.

1993“Contract Shop Epistemology: Credibility and problem construction in applied social sciences." Social Studies of Science 27: 363-394.

Coats, A.W.

1993 The Sociology and Professionalization of Economics. Londen and New York: Routledge.

Cozzens, S. and Woodhouse, E.J .

1995 “Science, Government and the Politics of Knowledge" Pp. 533-553 in Jasanoff et al. (eds.), Handbook of Science and Technology Studies. Thousan Oaks: Sage. 
Etzkowitz, H. and Leydesdorff, L.

1997 "A Triple Helix of University-IndustryGovernment Relations." Pp. 155-162 in Etzkowitz, Leydesdorff (eds.), Universities and the Global Economy, A Triple Helix of University-Industry-Government Relations. London and Washington: Pinter.

Funtowicz, S.O. and Ravetz, J.R.

1993 "The Emergence of Post-Normal Science." Pp. 85-126 in Schomberg (ed.), Science, Politics and Morality, Scientific Uncertainty and Decision Making. Dordrecht: Kluwer.

Galbraith, J.K.

1991 A HistoryofEconomics, The Pastas the Present. Harmondsworth: Penguin Books.

Gerlach, K.

1993 "Anreizstruktur und Forschungsaktivitäten in wirtschaftwissenschaftlichen Fachbereichen" (Incentive Structures and Research Activities in Economic Subfields). Pp. 245-268 in Schmidt-Schönbein (ed.), Die ökonomischeWissenschaft und ihr Betrieb (Economic Science and its Functioning). Frankfurt a.M. and New York: Campus.

Gibbons, M. et al.

1994 The New Production of Knowledge, The Dynamics of Science and Research in Gieryn, $\mathrm{T}$ Contemporary Societies. London: Sage.

1995 “Boundaries of Science." Pp. 393-443 in Jasanoff et al. (eds.), Handbook of Science and Technology Studies. London and Thousand Oaks: Sage.

Godin, B.

1998 “Writing Performative History:Thenew Atlantis? (review of Gibbons, M., et al., 1994, The New Production of Knowledge)." Social Studies of Science 28: 465-483.

Hagendijk, R.P.

1990 "Structuration Theory, Constructivism and Scientific Change." Pp. 43-66 in Cozzens, Gieryn (eds.), Theories of Science in Society. Bloomington: Indiana University Press.
Hall, P.A.

1989 “Conclusion.” Pp. 361-391 in Hall (ed.), The Political Power of Economic Ideas, Keynesianism Across Nations. Princeton: Princeton University Press. Hartmann, I.

1990 Begutachtung in der Forschungsförderung, DieArgumente der Gutachter in der Deutschen Forschungsgemeinschaft (Review Procedures in Research Funding, The Arguments of the Reviewers in the German Research Society). Frankfurt a.M.: Fischer.

Hohn, H.-W. and Schimank, U.

1990 Konflikte und Gleichgewichte im Forschungssystem, Akteurkonstellationen und Entwicklungspfade in der staatlich finanzierten außeruniversitären Forschung (Conflictsand Balances in the Research System, Actor Constellationsand Development Paths in Publicly-Funded Non-University Research). Frankfurt a.M. and New York: Campus.

Jacob, M..

1997 "Life in the Triple Helix: The contract researcher, the university and the knowledgesociety." Science Studies 10: 35-49.

Karpen, U.

1991 "The University within the Research System - The German experience." Pp. 135-160 in Orsi-Battaglini, Monaco (eds.), The University in the Research System, An International Comparison, Science and Society, Constitutional Problems, The National Experiences. Baden-Baden: Nomos.

Kirman, A. and Dahl, M

1996 “Economic Research in Europe." EUI Monographs in Economics. Florence: European University Institute.

Knemeyer, F.L.

1996 "Hochschulautonomie/ Hochschulverwaltung" (University Autonomy/ University Administration). Pp. 237257 in Flämig et al. (eds.), Handbuch desWissenschaftsrechts (Handbook of Science Administration). Heidel berg and New York: Springer. 
Latour, B.

1987 Science in Action, How to Follow Scientists and Engineers through Society. Milton Keynes: Open University Press. Leydesdorff, L. and Etzkowitz, $\mathrm{H}$.

1996 “Emergence of a Triple Helix of University-Industry-Government Relations." Science and Public Policy 23: 279-286.

Mayntz, R.

1991 “Scientific Research and Political Intervention - The structural development of publicly financed research in the Federal Republic of Germany." Pp. 4562 in Orsi-Battaglini, Monaco (eds.), TheUniversity in the Research System, An International Comparison, Science and Society, Constitutional Problems, The National Experiences. BadenBaden: Nomos.

Mayntz, R. and Schimank, U.

1998 “Linking Theory and Practice: Introduction." Research Policy 27: 747-755.

Medema, S.G. and Samuels, W.J

1996 “How Should Economists Do Economics? An integrative essay." Pp. 260-293 in Medema, Samuels (eds.), Foundations of Research in Economics: How do Economists do Economics? ChelMonti, M. tenham: Edward Elgar.

1997 Der Binnenmarkt und das Europa von morgen, Ein Bericht der Europäischen Kommission (Thelnternal M arket and the Europe of Tomorrow, A Report of the European Commission). LuxemOECD burg: European Commission.

1997 Societal Cohesion and the Globalising Economy, What Does the Future Hold? Paris: Organisation for Economic CoOperation and Development.

Pickering, A.

1992 “From Scienceas Knowledgeto Science as Practice." Pp. 1-26 in Pickering (ed.), Science as Practice and Culture. Chicago and London: University of Chicago Press.

Polanyi, K.

1957 The Great Transformation, The Political and Economic Origins of OurTime. Boston: Beacon Press.
Rip, A.

1994 "The Republic of Science in the 1990s." Higher Education 28: 3-23.

Schimank, U.

1994 "Autonomie und Steuerung wissenschaftlicher Forschung" (Autonomy and Guidance of Scientific Research). Pp. 409-432 in Derlien, Gerhardt, Scharpf (eds.), Systemrationalität und Partialinteresse (System Rationality and Partial Interests). Baden-Baden: Nomos.

Schimank, U.

1995 Hochschulforschung im Schatten der Lehre (University Research in the Shadow of Teaching). Frankfurt a.M. and New York: Campus.

Schimank, U.

1996 “Universities and Extra-University Research Institutes, Tensions within stable institutional structures." Pp. 111124 in Meyer-Krahmer (ed.), Science and Technology in Germany. London: Cartermill.

Shinn, T.

1999 “Change or Mutation? Reflections on the Foundations of Contemporary Science" Social Science Information 38: 149-176.

Wagner, $\mathrm{P}$.

1990 Sozial wissenschaften und Staat, Frankreich, Italien, Deutschland 1870-1980 (Social Sciences and the State, France, Italy, Germany 1870-1980). Frankfurt a.M. and New York: Campus.

Weingart, $P$.

1997 “From 'Finalization' to 'Mode 2': Old wine in new bottles?" Social Science Information 36: 591-613.

Weir, M. and Skocpol, T.

1985 "State Structures and the Possibilities for 'Keynesian' Responses to the Great Depression in Sweden, Britain and the United States." Pp. 107-163 in Evans et al. (eds.), Bringing the State Back In. Cambridge: Cambridge University Press.

Whitley, R.

1984 The Intellectual and Social Organization of theSciences. Oxford: Clarendon Press. 
Wilts, A.S.

1999 Institutionelle Vermittlungsmechanismen zwischen Wissenschaft und Praxis, am Beispiel der universitären und außeruniversitären Wirtschaftsforschung in Deutschland (Institutionalised Linking Mechanisms between Science and Practice, University and Non-University Economic Research in Germany). Research report. Cologne: Max Planck Institute for the Study of Societies.

Wissenschaftsrat

1998 Stellungnahme zu den Wirtschaftsforschungsinstituten der Blauen Liste in den alten Ländern (Assessment of the Economic Research Institutes in Western Germany). Cologne: Wissenschaftsrat.

Wittrock, B., Wagner, P. and Wollmann, H.

1991 "Social Science and the Modern State, Policy knowledge and political institutions in Western Europe and the United States." Pp. 28-85 in Wagner et al. (eds.), Social Sciences and Modern States, $\mathrm{Na}$ tional Experiences and Theoretical Crossroads. Cambridge: Cambridge University Press.

Arnold Wilts

MaxPlanck Institute for

the Study of Societies,

Cologne, Germany 